\title{
The Law Enforcement Against The Crime Of Illegal Mining
}

\author{
Keris Aji Wibisono*) and Umar Ma'ruf*') \\ *) Central Kalimantan Police, E-mail: kerisaji mh36@std.unissula.ac.id \\ ${ }^{* *}$ Faculty of Law, Universitas Islam Sultan Agung (UNISSULA) Semarang
}

\begin{abstract}
This study aims to determine law enforcement against the criminal act of illegal mining in the jurisdiction of the Central Kalimantan Regional Police and the obstacles that arise in law enforcement of the criminal act of illegal mining in the jurisdiction of the Central Kalimantan Regional Police and their solutions. The approach method used is sociological juridical, descriptive analytical research specifications, types and sources of data using primary and secondary data, data collection methods are field studies and literature studies, while the data analysis method uses qualitative analysis. The results of the study indicate that law enforcement for the criminal act of illegal mining in the jurisdiction of the Central Kalimantan Regional Police is carried out through preventive and repressive efforts. Repressive efforts are carried out with outreach activities to the community at the Polres and Polsek levels, while repressive efforts through a series of investigative actions. There are several obstacles in the law enforcement process, namely the presence of irresponsible individuals, limited facilities and infrastructure and a lack of legal awareness from the community.
\end{abstract}

Keywords: Law Enforcement; Criminal Acts; Illegal Mining.

\section{Introduction}

Indonesia is a country that is rich in minerals (mining), in which the rights of these minerals are controlled by the state. This is as emphasized in Article 33 paragraph (3) of the 1945 Constitution of the Republic of Indonesia which states that "Earth and water and the natural resources contained therein are controlled by the State and used as much as possible for the prosperity of the people".

The principle contained in the provisions of Article 33 paragraph (3) of the 1945 Constitution of the Republic of Indonesia means that the government as the implementer of state policy is obliged to manage and utilize natural resources as much as possible for the prosperity of the people. ${ }^{1}$ The natural resources of the Indonesian people, if managed properly, will contribute to the country's economic development. $^{2}$

Mining is carried out based on procedures and prerequisites that have been stipulated in several laws and regulations governing mining. Mining law is the entire legal system that regulates the authority of the State in the management of minerals (mines) and regulates relations between countries and individuals

\footnotetext{
1Ida Ayu Eling Purnama Sari, "Kewenangan Pemerintah Daerah Dalam Pengelolaan Izin Usaha Pertambangan Di Kabupaten Minahasa Utara", Lex Administratum, Vol. III No. 4, June 2015, url : https://ejournal.unsrat.ac.id/index.php/administratum/article/view/8675

2 Gatot Supramano, 2012, Hukum Pertambangan Mineral dan Batubara di Indonesia, Rineka Cipta, Jakarta, p.1
} 
and/or legal entities in the management and utilization of minerals (mines). ${ }^{3}$ In Indonesia, it is regulated in Act No. 4 of 2009 concerning Mineral and Coal Mining as amended to Act No. 3 of 2020 concerning Amendments to Act No. 4 of 2009 concerning Mineral and Coal Mining (Minerba Law). In addition, mining that causes environmental damage is also regulated in Act No. 32 of 2009 concerning Environmental Protection and Management.

In practice, many mining activities are carried out without a permit or often referred to as illegal mining. Illegal mining is an activity carried out by people or the community without permission from the authorized official. These activities are prone to accidents and work safety, even pollution and uncontrolled environmental damage. ${ }^{4}$

Illegal mining carried out not according to procedures, so that it has an impact on environmental losses such as water pollution, air pollution, soil pollution, and even threatens people's lives. However, law enforcement efforts against illegal mining are sometimes carried out half-heartedly, especially economically, these activities have helped reduce poverty and unemployment which are still a problem for the local economy in many areas in Indonesia. ${ }^{5}$ This is as KLHK data which states that behind illegal mining there is a significant social and economic impact for miners, namely an increase in welfare by $77 \% .{ }^{6} \mathrm{On}$ the other hand, in accordance with the provisions of laws and regulations, illegal mining activities are criminal acts which in a positivistic perspective must be implemented or enforced. One of the areas that is rife with illegal mining activities is the province of Central Kalimantan, considering that the area is rich in mining materials.

Law enforcement against the criminal act of illegal mining in the jurisdiction of the Central Kalimantan Regional Police has been going well but has not been maximized. In practice, it is influenced by several factors that can affect law enforcement, namely the law itself, law enforcement factors, facilities or facilities, community factors, cultural factors. ${ }^{7}$ This study aims to determine law enforcement against the criminal act of illegal mining in the jurisdiction of the Central Kalimantan Regional Police and the obstacles that arise in law enforcement of the criminal act of illegal mining in the jurisdiction of the Central Kalimantan Regional Police and their solutions.

\section{Research Methods}

\footnotetext{
${ }^{3}$ Salim HS, 2012, Hukum Pertambangan di Indonesia, Rajawali Pers, Jakarta, p.8

${ }^{4}$ Nandang Sudrajat, 2010, Teori dan Praktik Pertambangan Indonesia Menurut Hukum, Jakarta : Pustaka Yustisia, p. 76.

${ }^{5}$ Hanan Nugroho, Pandemi Covid-19: Tinjau Ulang Kebijakan Mengenai PETI (Pertambangan Tanpa Izin) di Indonesia, The Indonesian Journal of Development Planning, Volume IV No. 2 - June 2020, url : https://journal.bappenas.go.id/index.php/ipp/article/view/112

6 Ahmad Redi, Dilema Penegakan hukum Penambangan Mineral dan Batubara Tanpa Izin pada Pertambangan Skala Kecil, Jurnal Rechtsvinding, Volume 5, Nomor 3, December 2016, url : https://rechtsvinding.bphn.go.id/ejournal/index.php/jrv/article/view/152

${ }^{7}$ Soerjono Soekanto, 2004, Faktor-Faktor Yang Mempengaruhi Penegakan Hukum, Jakarta : PT. Raja Grafindo Persada, p.6.
} 
The approach method used in this research is sociological juridical, namely: research based on normative legal science and examines how the law works in society. ${ }^{8}$ The research specification is analytical descriptive, the sources and types of data used are primary data and secondary data. The data collection method is carried out through field studies and literature studies while the data analysis method uses qualitative analysis.

\section{Results and Discussion}

\subsection{Law Enforcement of Illegal Mining Crime in the Legal Territory of the Central Kalimantan Police}

Mining according to Article 1 point 1 of Act No. 3 of 2020 concerning amendments to Number 4 of 2009 concerning Mineral and Coal Mining (Minerba Law) is part or all of the stages of activities in the framework, management and exploitation of minerals or coal which include general investigation, exploration , feasibility studies, construction, mining, processing and/or refining or development and/or utilization, transportation and sales, as well as post-mining activities. The provisions of the article indicate that all mining activities from the research process to post-mining activities are a series of activities that must be legally accountable.

Mining activities cannot be carried out arbitrarily but must be based on the provisions of the applicable laws and regulations, which are currently based on Act No. 4 of 2009 concerning Mineral and Coal Mining as amended into Act No. 3 of 2020. Every business mining of strategic minerals and groups of vital minerals according to the Minerba Law can be carried out if a mining permit has been obtained beforehand. ${ }^{9}$

Mining activities without a permit (illegal mining) are a form of violation of the provisions of the Minerba Law. Illegal mining is a crime in the mining business carried out by individuals, groups of people, or companies/foundations with legal entities which in their operations do not have permission from government agencies in accordance with applicable regulations, which threaten criminal sanctions for anyone who because of his mistake violates the prohibition. The criminal provisions are regulated in the Minerba Law Article 158, Article 160 Paragraph (2), Article 161, Article 163 Paragraph (1) and Paragraph (2), and Article 164.10

The National Police as an institution of law enforcement officers who carry out the function of public services are required to be able to provide the best

\footnotetext{
${ }^{8}$ Mukti Fajar ND and Yulianto Achmad, 2013, Dualisme Penelitian Hukum Normatif dan Empiris, Yogyakarta: Pustaka Pelajar, p.47.

${ }^{9}$ Edy Kastro, "Penegakan Hukum Terhadap Tindak Pidana Penambangan Tanpa Izin (Illegal Mining) di Wilayah Hukum Kepolisian Resor Muara Enim", Edition No. XL Tahun XXXI March 2019, url : https://jurnal.um-palembang.ac.id/variahukum/article/view/1721

10 Dany Andhika Karya Gita, Amin Purnawan, Djauhari, "Kewenangan Kepolisian Dalam Menangani Tindak Pidana Pertambangan (Ilegal Mining) Menurut Undang-Undang Nomor 4 Tahun 2009 (Studi Di Kepolisian Negara Indonesia)", Jurnal Daulat Hukum, Vol 1 No 1 (2018),url: http://jurnal.unissula.ac.id/index.php/RH/article/view/2561
} 
service to the community by displaying the performance of a proportional and professional unit in their field. Article 13 of Law no. 2 of 2002 concerning the National Police of the Republic of Indonesia, states that the National Police has several main tasks, namely maintaining public security and order, enforcing the law and providing protection, protection and public services. ${ }^{11}$

Law enforcement efforts against illegal mining crimes at the Central Kalimantan Regional Police are carried out through preventive and repressive efforts. Preventive efforts are carried out by conducting socialization to the community at the Polres and Polsek levels in the jurisdiction of the Central Kalimantan Police. In this case, the ranks of the Central Kalimantan Regional Police routinely carry out socialization through the media of stop illegal mining banners to members of the community in their respective areas. Through banners, the officers asked the public not to carry out illegal mining in accordance with the Minerba Law. The public is advised not to carry out illegal mining, because if they commit a criminal act of illegal mining, they will be processed according to the laws and regulations. The socialization also aims to maintain security and order in order to remain conducive in the jurisdiction of the Central Kalimantan Police.

Repressive law enforcement against illegal mining is carried out through a series of investigations and investigations by the Ditreskrimsus Polda Central Kalimantan. The process of investigating the criminal act of illegal mining is basically the same as the process of law enforcement for criminal acts in general which is based on the Criminal Procedure Code. The investigation was carried out on the basis of a report on the existence of a criminal act of illegal mining which was then followed up with investigations and investigations. The main activities in the investigation process are investigations; inspection; action consisting of summons, arrest, detention, search, confiscation; and the last stage is the stage of completion and submission of case files to the public prosecutor.

Based on the results of research at the Central Kalimantan Police, the data on the number of illegal mining cases in 2018 to 2020 are as follows:

Table 1

Number of Illegal Mining Cases at the Central Kalimantan Police in 2018 to 2020

\begin{tabular}{lll}
\hline Year & Amount & Number of suspects \\
\hline 2018 & 27 & 27 \\
\hline 2019 & 34 & 34 \\
\hline 2020 & 11 & 26 \\
\hline
\end{tabular}

Source: Central Kalimantan Police, 2021

Based on the table above, it can be seen that in 2018 there were 27 cases of illegal mining with 27 suspects handled by the Central Kalimantan Police, while in 2019 there were 34 cases with 34 suspects and in 2020 there were 11 cases with 26 suspects.

\footnotetext{
11 Darmadi Prapto Pamungkas, "Efektivitas Penyidikan Tindak Pidana Penambangan Emas Tanpa Izin Di Kabupaten Solok Selatan (Studi pada Direktorat Reserse Kriminal Khusus Kepolisian Daerah Sumatera Barat), Unes Law Review, Volume 1, Issue 2, December 2018, url : https://media.neliti.com/media/publications/270555-efektivitas-penyidikan-tindak-pidana-pen$\underline{\text { 519761e3.pdf }}$
} 
Based on the description above, it can be seen that the efforts to enforce the law on illegal mining in the jurisdiction of the Central Kalimantan Regional Police are in line with the concept of law enforcement proposed by Andi Hamzah. Which states that the term law enforcement is often misinterpreted as if it only operates in the field of criminal law or only in the repressive field, when in fact law enforcement includes preventive and repressive efforts. ${ }^{12}$

Law enforcement is an attempt to make the ideas of justice, legal certainty and social benefits a reality. ${ }^{13}$ In line with this concept, efforts to enforce the law on illegal mining in the jurisdiction of Central Kalimantan Police have attempted to achieve justice, legal certainty and benefit. This can be seen from the existence of preventive efforts, namely in the form of socialization to the community which aims to provide education to the community so that they do not carry out illegal mining. However, in the event that the community still commits criminal acts, then repressive efforts are carried out through investigative actions.

\subsection{Obstacles Emerging in Law Enforcement of Illegal Mining Crimes in the Legal Area of the Central Kalimantan Police and their Solutions}

The obstacles faced by investigators in the jurisdiction of the Central Kalimantan Regional Police in law enforcement of the criminal act of illegal mining are as follows:

- There are backups from irresponsible people

It is no secret, in illegal mining activities, the perpetrators are backed up by irresponsible elements such as law enforcement officials, government officials, and traditional stakeholders. This makes it difficult for officers to carry out investigations, because usually the perpetrators have, for example, had raids, the perpetrators have received information about raids. The solution to overcome this is the provision of spiritual and mental guidance for all members of the National Police in the area of the Central Kalimantan Regional Police. This activity aims to improve human resources through religious mental guidance or development. With this activity, it is hoped that members of the Police can fortify themselves from actions that are not commendable.

- Limited facilities and infrastructure

The limitations of facilities and infrastructure owned by the Ditreskrimsus Polda Central Kalimantan include limited means of transportation to reach illegal mining locations, the number of personnel that is still lacking, as well as large costs considering that crime scenes are spread in many places. The solution to overcome these obstacles is to strive for the availability of adequate facilities and infrastructure and an adequate budget. In addition, it also needs support from educated and skilled law enforcement officers so that they can carry out their duties professionally.

- Lack of legal awareness from the community

Illegal mining crimes in the Central Kalimantan region are increasingly massive and uncontrolled. Miners do not understand the procedures for protecting the

\footnotetext{
12 Andi Hamzah, 2010, Hukum Acara Pidana Indonesia, Jakarta : Sinar Grafika, p.134.

${ }^{13}$ Satjipto Rahardjo, Penegakan Hukum Progresif, (Jakarta : Ghalia Indonesia, 2011), p. 14.
} 
environment so that once the mining activities are completed they will just leave their excavations without doing any rehabilitation. This happens because people do not have the knowledge to protect the environment properly. In addition, the community also does not understand the regulations that prohibit illegal mining. The community does not know what the negative impacts of illegal mining are. The solution to overcome these obstacles is to routinely conduct outreach to the community not to carry out illegal mining activities.

The obstacles mentioned above affect law enforcement against illegal mining at the Central Kalimantan Police. As Soerjono Sokanto's opinion that law enforcement is influenced by legal factors themselves, law enforcement, facilities and infrastructure, society and legal culture. In this case, law enforcement officers also influence the law enforcement process. The existence of individuals who become backups of the perpetrators can hinder law enforcement efforts. Likewise, the limitations of facilities and infrastructure as well as the people who are not supportive of illegal mining law enforcement have hampered the law enforcement process against illegal mining at the Central Kalimantan Police.

\section{Closing}

Law enforcement of the criminal act of illegal mining in the jurisdiction of the Central Kalimantan Regional Police is carried out through preventive and repressive efforts. Repressive efforts are carried out through outreach activities to the community at the Polres and Polsek levels, while repressive efforts are carried out through a series of investigative actions. There are several obstacles in the law enforcement process, namely the presence of irresponsible individuals, limited facilities and infrastructure and a lack of legal awareness from the community.

Therefore, there is a need for guidance, supervision and education efforts from the government to overcome illegal mining. In addition, there needs to be a transfer of community activities from mining activities to agriculture, trade and so on.

\section{References}

\section{Journal}

[1] Ahmad Redi, Dilema Penegakan hukum Penambangan Mineral dan Batubara Tanpa Izin pada Pertambangan Skala Kecil, Jurnal Rechtsvinding, Volume 5, Nomor 3, December 2016, url : https://rechtsvinding.bphn.go.id/ejournal/index.php/jrv/article/view/152

[2] Dany Andhika Karya Gita, Amin Purnawan, Djauhari, "Kewenangan Kepolisian Dalam Menangani Tindak Pidana Pertambangan (Ilegal Mining) Menurut Undang-Undang Nomor 4 Tahun 2009 (Studi Di Kepolisian Negara Indonesia)", Jurnal Daulat Hukum, Vol 1 No 1 (2018),url: http://jurnal.unissula.ac.id/index.php/RH/article/view/2561

[3] Darmadi Prapto Pamungkas, "Efektivitas Penyidikan Tindak Pidana Penambangan Emas Tanpa Izin Di Kabupaten Solok Selatan (Studi pada Direktorat Reserse Kriminal Khusus Kepolisian Daerah Sumatera Barat), Unes Law Review, Volume 1, Issue 2, December 2018, url : 
https://media.neliti.com/media/publications/270555-efektivitaspenyidikan-tindak-pidana-pen-519761e3.pdf

[4] Edy Kastro, "Penegakan Hukum Terhadap Tindak Pidana Penambangan Tanpa Izin (Illegal Mining) di Wilayah Hukum Kepolisian Resor Muara Enim", Edition No. XL Tahun XXXI March 2019, url : https://jurnal.umpalembang.ac.id/variahukum/article/view/1721

[5] Hanan Nugroho, Pandemi Covid-19: Tinjau Ulang Kebijakan Mengenai PETI (Pertambangan Tanpa Izin) di Indonesia, The Indonesian Journal of Development Planning, Volume IV No. 2 - June 2020, url : https://journal.bappenas.go.id/index.php/ipp/article/view/112

[6] Ida Ayu Eling Purnama Sari, "Kewenangan Pemerintah Daerah Dalam Pengelolaan Izin Usaha Pertambangan Di Kabupaten Minahasa Utara", Lex Administratum, Vol. III No. 4, June 2015, url : https://ejournal.unsrat.ac.id/index.php/administratum/article/view/8675

\section{Book}

[1] Andi Hamzah, 2010, Hukum Acara Pidana Indonesia, Jakarta : Sinar Grafika.

[2] Gatot Supramano, 2012, Hukum Pertambangan Mineral dan Batubara di Indonesia, Rineka Cipta, Jakarta.

[3] Mukti Fajar ND dan Yulianto Achmad, 2013, Dualisme Penelitian Hukum Normatif dan Empiris, Yogyakarta: Pustaka Pelajar.

[4] Nandang Sudrajat, 2010, Teori dan Praktik Pertambangan Indonesia Menurut Hukum, Jakarta : Pustaka Yustisia.

[5] Salim HS, 2012, Hukum Pertambangan di Indonesia, Rajawali Pers, Jakarta.

[6] Satjipto Rahardjo, 2011, Penegakan Hukum Progresif, Jakarta : Ghalia Indonesia.

[7] Soerjono Soekanto, 2004, Faktor-Faktor Yang Mempengaruhi Penegakan Hukum, Jakarta : PT. Raja Grafindo Persada.

\section{Regulations}

[1] Constitution of the Republic of Indonesia 1945

[2] Criminal Code

[3] Criminal Procedure Code

[4] Act No. 2 of 2002 concerning the Indonesian National Police. Jakarta, 2002

[5] Act No. 20 of 2001 concerning Amendments to Law of the Republic of Indonesia Number 31 of 1999 concerning Eradication of Criminal Acts of Corruption. 